\title{
The Determinants of Capital Buffer in the Turkish Banking System
}

\author{
Gonca Atici ${ }^{1} \&$ Guner Gursoy ${ }^{2}$ \\ ${ }^{1}$ Department of Business Administration \& Banking and Finance, T.C. Maltepe University, Istanbul, Turkey \\ ${ }^{2}$ Institute of Social Sciences, Istanbul Kemerburgaz University, Istanbul, Turkey \\ Correspondence: Gonca Atici, T.C. Maltepe University, Marmara Egitim Koyu, 34857, Maltepe, Istanbul, Turkey. \\ Tel: 90-216-626-1024. E-mail: goncaatici@maltepe.edu.tr
}

Received: November 27, 2012

Accepted: December 11, 2012 Online Published: December 13, 2012

doi:10.5539/ibr.v6n1p224

URL: http://dx.doi.org/10.5539/ibr.v6n1p224

\begin{abstract}
The purpose of this study is to analyze the determinants of capital buffer in the Turkish Banking system and to estimate the cyclicality of capital buffer using a panel data of 87 banks covering the period 1988-2009. The data is based on the reports published by the Banks Association of Turkey. Two-step Generalized Method of Moments is implemented by using Arellano-Bond linear dynamic panel-data estimator. The study is focused on: i) economic growth, ii) asset size, iii) return on equity and iv) non-performing loans as the determinants of capital buffer. It is observed that commercial banks, including the banks under the control of Savings Deposit and Insurance Fund, move procyclically, where commercial banks, excluding the banks under Savings Deposit and Insurance Fund, fluctuate countercyclically. This finding is noteworthy since it is parallel to BASEL III, where structuring a countercyclical capital framework is emphasized.
\end{abstract}

Keywords: capital adequacy, capital buffer, banking sector, business cycle

\section{Introduction}

In the world of global financial crises, banking sector appeals significant interest. Because banks are the key players in the financial system, their way of dealing with the risky environment of today motivate researchers to look at the issue from different perspectives. Among those, capital requirement of a bank is vitally critical especially during the financial crisis times. Relation between capital requirement and business cycle attracts significant attention in literature. Since the seminal paper of Modigliani and Miller (1958), capital structure in companies has been among the most important topic in the finance area and this importance has even grown for banks after the deregulation period started in the 1970s as emphasized by Stolz (2007). Discussions on pro or countercyclicality of banks' capital requirement have reached to a new dimension in June 2004, when the Basel Committee on Banking Supervision published the final draft of the revised framework for capital measurement and capital standards, known as Basel II, by the Bank for International Settlements (2004). Because Basel II requires banks to maintain the capital adequacy ratio above the $8 \%$ solvency coefficient of Basel I, this new regulation brings additional burden on banks. Banks are in dilemma to maintain "sufficiently enough" capital adequacy ratios which show healthiness of banks with their ability to absorb potential future losses and confidence level in the banking sector.

In literature, the term 'capital buffer' is defined as the amount of capital, banks hold in excess of that required of them by national regulators as denoted by Jokipii and Milne (2008) and often viewed as a "cushion" against insolvency crises as specified by Eichberger and Summer (2005). Banks hold capital buffer for a variety of motivations and justifications based on: (a) their internal capital assessment models determined by their own risk appetite and assumptions, (b) the tendency to reflect their "soundness" with higher capital buffers for good ratings as argued by Jackson (1999), (c) the need to insure themselves by having capital buffers set by the regulators as proposed by Marcus (1984), Milne (2004) and Milne and Whalley (2001), and (d) the likely growth opportunities as introduced by Jokipii and Milne (2008). Capital buffer brings both advantages and disadvantages. For example, Heuvel (2008) finds welfare cost of capital significantly large. Therefore, banks need to consider the trade-off between advantages and costs associated with holding capital buffer. Restricting bank activities through a higher capital requirement ratio is expected to be negatively associated with bank development, adversely affecting credit expansion and credit growth. However, there are some contradictory evidences in the literature. Goddard, Molyneux and Wilson (2004) find a positive relation between the 
capital-to-asset ratio and profitability for the European banks. The introduction of risk-based capital standards is an attempt to eliminate the potentially negative effects of capital requirements as cited by Ayuso, Perez and Saurina (2004). Besides, the Basel Committee considers determining "right" buffer size as an important risk management task for banks and it suggests regular stress testing as denoted by Peura and Jokivuolle (2004). Committee's "good" intentions are criticized because of the likely procyclicality side effect. As Danielsson et al. (2001) argue, this side effect of co-movements in capital requirements and business cycles may induce banks to reduce lending during recessions due to high capital requirements. The opposite dynamics may apply during booming economies and this mechanism tends to worsen business cycle peaks and troughs as discussed by Pederzoli and Torricelli (2005). Significant amount of researchers focus on the determinants of capital buffer and its relation with the business cycle (Note 1). However, there is not a consensus on findings. Ayuso et al. (2004) report a negative effect of business cycle on the capital buffers of Spanish Banks. Likewise, Stolz and Wedow (2005, 2011) find strong evidence that capital buffers behave countercyclically. Although, Lindquist (2003) asserts a positive effect on the capital buffer of Norwegian Banks, in his later study (2004) he reports a negative effect on the capital buffer. Jokipii and Milne (2008) find a positive co-movement for the recently accessed 10 member countries joined the European Union (EU) in May 2004.

In this study, we try to analyze the issue for the banking system of Turkey. We intend to contribute to the literature in two ways: (a) by exploring the crisis management experience of the Turkish banking sector from the capital adequacy perspective, and (b) by exploring the cyclicality behavior of the sector with a new category for the Savings Deposit and Insurance Fund (SDIF) banks. In this regard, the determinants of capital buffer for Turkish banks and the relation between capital buffer and the business cycle are examined with the panel data of the Turkish banks during the sample period of 1988-2009. In this environment, Generalized Method of Moments (GMM) estimator has been employed by reviewing the literature.

The structure of the paper is as follows: Section 2 summarizes the implementation of capital buffer in the Turkish banking sector. Section 3 introduces data and methodology. Section 4 presents the empirical results. Section 5 concludes the paper by discussion and further research ideas.

\section{Capital Buffer in the Turkish Banking Sector in Brief}

Turkish banking sector has experienced frequent financial crises in the last two decades and learned from the previous mistakes with high cost as argued by Atici and Gursoy (2011). When the crises management experience is supported by the restructuring efforts of financial and banking system, the result turned to a success story during the latest global financial crisis. Turkish banking sector is affected from the global financial crisis in a relatively better scale compared to the European banking sector and it is recovered in a relatively shorter period. The higher capital adequacy ratios of the Turkish banks seem to have contributed to this accomplished result. In the Turkish Banking system, we began to witness high capital adequacy ratios by the capital adequacy standard ratio (Basel I) that has been put into effect in 1989. The capital buffer ratios have increased well above the legal requirement of $8 \%$ and even the target ratio of $12 \%$ (Note 2) after the banking and liquidity crisis of 2000 and 2001 in Turkey. The ratio is around $19 \%$ for the period of $2001-2007$, around $21 \%$ for the following two years, $18.9 \%$ in 2010 and $16.5 \%$ in 2011 as cited in BRSA Report (2012). With a transition period defined as July 2011 - June 2012, Turkish banking sector is announced to be performing in compliance with Basel II requirements by the second half of 2012 and definitive implementation process has begun as of July 2012.

\section{Data and Methodology}

The relation of capital buffer and its cyclicality in the Turkish banking sector is examined in light of the models listed in literature. Ayuso et al. (2004) established GMM (Note 3) estimation of capital buffer with the variables of return on equity (ROE), non-performing loans (NPL), size and the growth of gross domestic product (GDPG) to analyze the effect of business cycle on the capital buffer of Spanish commercial and savings banks for the period 1989-2000. Lindquist (2004) applied the model of Ayuso et al. (2004) to estimate the capital buffer of Norwegian banks for the period of 1995-2001. Estrella (2004) developed a dynamic model of optimum bank capital with the data of commercial banks in the United States collected for the period between 1984 - 2001. Alfon, Argimón, and Bascuñana-Ambrós (2005) analyzed the determinants of the capital ratio of banks in the United Kingdom with a GMM framework based on Ayuso et al. (2004) and Lindquist (2004). The independent variables were risk, size, GDPG, proportion of commercial and retail deposits over total deposits, trade and foreign ownership. Stolz and Wedow $(2005,2011)$ analyzed the effect of the business cycle on the regulatory capital buffer of German banks with a GMM estimator as well. Business cycle, return on asset, size, liquidity, loan loss, merger and bank type were the independent variables of the model established. Bikker and Metzemakers (2007) investigated the determinants of capital targets of commercial banks and their potential 
sensitivity to business cycle by using GMM estimator established for 29 Organization for Economic Co-operation and Development (OECD) countries for a period from 1992 to 2001. Jokipii and Milne (2008) developed an unbalanced panel data for the period 1997-2004 to realize the extent of co-movement between capital buffer and business cycle. ROE, NPL to total loans and size were the explanatory variables. Finally, Fonseca and Gonzales (2010) analyzed the bank and country determinants of capital buffers using GMM with a panel data of 1337 banks in 70 countries between 1992 and 2002. By the light of the previous literature, we have established our model as presented in Equation (1).

$$
\begin{gathered}
\boldsymbol{B U} \boldsymbol{F}_{i t}=\alpha_{0} B U F_{i, t-1}+\alpha_{1} G D P G_{i t}+\alpha_{2} S_{I Z E_{i t}}+\alpha_{3} R O E_{i t}+\alpha_{4} N P L_{i t}+\alpha_{5} L O G_{i t}+\alpha_{6} P_{R O F I T_{i t}}+\alpha_{7} L^{2 O T A_{i t}}+\alpha_{8} \\
M E R G E R+n_{i}+\varepsilon_{i t}
\end{gathered}
$$

where $B_{F_{t}}$ denotes the capital buffer banks hold in excess of the regulatory minimum capital requirement as specified in Appendix D, GDPG is the annual growth of gross domestic product, SIZE is the natural logarithm of total assets, ROE is the net income over total equity, NPL is the ratio of loans under follow-up over total loans as a measure of the true riskiness of bank portfolios, LOG is the loan growth to capture the changes in credit demand, PROFIT is the bank profit after tax, LOTA is loans over total assets as a measure of bank risk and MERGER is the dummy variable that is "one" if a bank has taken over by another bank in the same year and zero otherwise. The subscripts $i$ and $t$ denote bank and time period respectively. " $\eta_{i}$ " is an unobservable variable that captures idiosyncratic features of each bank that are constant over time and " $\varepsilon$ " is the random shock.

The capital buffer variable of $\mathrm{BUF}_{\mathrm{i}, \mathrm{t}-1}$ is a lagged dependent variable intends to capture persistence of capital buffer as argued by Ayuso et al. (2004) while its coefficient may be interpreted as a measure of adjustment cost with its expected positive sign. The GDPG variable is added to Equation (1) as a macroeconomic indicator to explore the impact of business cycle on capital buffer. SIZE as the first bank specific control variable included to Equation (1) as used by Stolz and Wedow (2005, 2011) and Alfon and Argimon, (2005). This variable may affect the capital buffer through several ways such that: (a) large banks have lower possibility of negative shock to their capital because of their easier access to investment and diversification opportunities, (b) large banks would be the first to rescue and support in a financially distressed environment due to prevent negative chain reactions, and (c) size of a bank may be another reason for having an access to capital. Because of these listings, SIZE variable is expected to have a negative sign. ROE is the second bank specific control variable included to the Equation (1). Direct costs of remunerating the excess capital are approximated by return on equity of each institution. A negative sign may suggest that the higher the cost of the capital, the bigger the negative effect on the capital buffer. Alfon et al. (2005), Ayuso et al. (2004) and Boucinha (2008) recorded negative relation between ROE and capital. On the contrary, Berger (1995), Nier and Baumann (2006) and Flannery and Rangan (2008) found a positive relation between ROE and the cost of capital. When there is information asymmetry, a significant proportion of fluctuations in bank earnings tend to be kept as retained earnings, which in turn will cause an increase in capital ratio. NPL is the third bank-specific control variable in the Equation (1) as used by Ayuso et al. (2004). If banks set their capital in line with the true riskiness of their portfolios, then a positive relation will be expected. On the other hand, as an ex-post measurement of the risk assumed by the institutions, a negative sign could be witnessed by the banks where higher credit risk materialized lowered the excess. As Basel requires banks to keep different capital ratios towards different types of exposures (e.g. direct-lending, contingent-lending, underwriting) banks might vary their capital buffers depending on their risk assessment of their portfolios. With this justification, four new variables are added to the Equation (1), namely LOG, PROFIT, LOTA, and MERGER. We believe that controlling for LOG would be meaningful for a correct interpretation of NPL as suggested by Boucinha (2008). LOG, enables us to capture changes in credit demand. If banks have not anticipated a high credit growth, this could lead a reduction in their capital buffers. On the other hand, an upswing in loans implies an increase in capital requirements. However, when adjusting capital is costly, then a transitorily reduction in capital buffer is likely to happen. The next variable is PROFIT. Banks can increase their capital buffer through retained earnings, but this is an uncertain option if profits are highly volatile. Lindquist (2004) found a significant negative relation between profit and capital buffer. Higher retained earnings could be expected to increase capital buffers, but also higher expected earnings could lead to a reduction in desired capital buffers. Although the expected sign of this variable is ambiguous, Jokipii and Milne (2008) report a positive relation. The fourth extension to Equation (1) is LOTA, as a measure of bank risk. Because LOTA points out a potential risk, its sign is expected to be positive. On the other hand, a negative sign would suggest that, banks choose to take greater risks with their assets by holding smaller capital buffers as argued by Fonseca and Gonzales (2010). Because Turkish banking sector has witnessed several mergers especially during the restructuring period, our final addition to Equation (1) will be MERGER. This dummy variable is one if a bank has taken over by another bank in the same year and zero otherwise. A negative coefficient on MERGER could 
suggest that merger consume capital or it could be the consequence of the merger between a well capitalized bank and a loosely capitalized one to rescue the weak from financial distress as argued by Kleff and Weber (2003). Whereas, a positive sign could be explained by precautionary behavior or simply by the acquisition of a strongly capitalized bank. Moreover, a positive sign could also mean that acquiring bank is typically better capitalized before a merger (Stolz \& Wedow, 2005).

Turkish Banks periodically prepare and present their financial statements in accordance with the Banking Act No:5411 and regulations of BRSA. According to the regulations of BRSA, independent auditors have to express an opinion on banks' financial statements based on their audit. By the completion of this process, the Banks Association of Turkey publishes statistical reports on the financial statements of Turkish Banks for informative purposes. Our data are based on the information published by the Banks Association of Turkey. The dataset used for the estimation covers the consolidated figures of 87 banks for the period from 1988 to 2009 , for 21 years. The period is set that long both to increase the number of observations and to analyze the relation between the business cycle and the capital buffers held by banks. We estimate the model for different categories (a) commercial banks, (b) commercial banks excluding the problematic SDIF banks, and (c) development and investment banks. The distribution of banks is summarized in Appendix A. Descriptive statistics of the variables and correlation matrixes of commercial banks and commercial banks excluding the SDIF banks are presented in Appendix B and Appendix C respectively. Evaluation of capital buffers in the Turkish banking sector is presented in Figure 1.

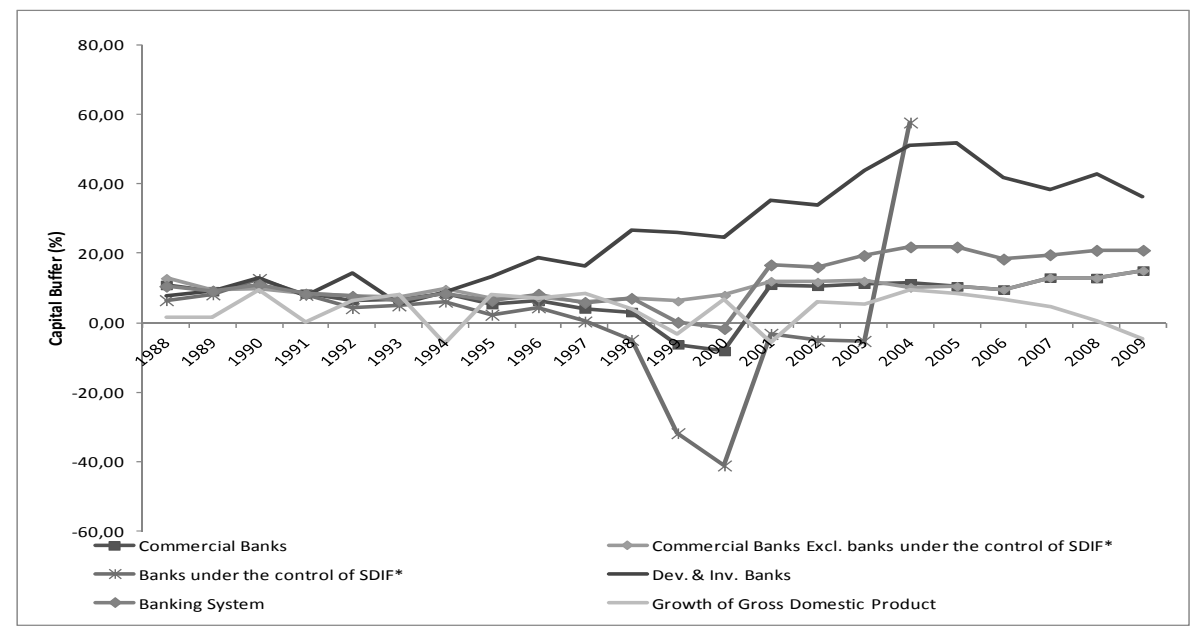

Figure 1. Evolution of capital buffers in Turkish Banks

Notes: Dev. \& Inv. Banks= Development and Investment Banks. *Banks under the control of Savings Deposit and Insurance Fund.

The development and investment banks as being too cautious with their special structures seem to operate with the highest capital buffers well above the GDP growth line. Capital buffers of commercial banks are considerably negative between the years of 1999 and 2000 as this group of banks consists of the problematic banks under the control of SDIF. When we exclude this problematic group of banks, the average capital buffer increase to $7 \%$ for the same period. Until 2006, the capital buffer of commercial banks excluding the problematic SDIF banks moves mostly above the GDP growth line. By 2006, we witness a diminishing GDP growth line while capital buffer has an uptrend as a precautionary measure against potential distress. Capital buffer of the SDIF banks reaches to its peak by 2004 and because they have eliminated from the banking system, this group lose its effect on the banking system for the same year.

\section{Empirical Results}

We estimate model (1) for (a) commercial banks (b) commercial banks excluding the SDIF banks, and (c) development and investment banks. First, we have transformed model (1) into first differences to obtain unbiased estimates. Because the lagged endogenous variable is included among the regressors and other explanatory variables are likely to be endogenous, GMM estimator is employed. In order to avoid model misspecification, three conditions should be satisfied under the GMM estimation (a) a significant first-order autoregressive model, AR (1) serial correlation, (b) lack of second-order autoregressive model, AR (2) serial correlation and (c) a high Sargan test statistic as specified by Arellano and Bond (1991) and Caporale, Raul, Sova, \& Sova (2009). The results of model (1) are listed in Table 1. 
Table 1. GMM estimation results

\begin{tabular}{|c|c|c|c|c|c|c|c|}
\hline & & \multicolumn{2}{|c|}{ Commercial banks } & \multicolumn{2}{|c|}{ Commercial banks excluding SDIF banks**** } & \multicolumn{2}{|c|}{ Development and investment banks } \\
\hline & & Coef. & p-value & Coef. & p-value & Coef. & p-value \\
\hline \multirow[t]{9}{*}{ Model 1} & $\mathrm{BUF}_{\mathrm{i}, \mathrm{t}-1}$ & $0.4939 * * *$ & 0.000 & $0.5807 * * *$ & 0.000 & $0.5445^{* *}$ & 0.011 \\
\hline & GDPG & $0.0250 * * *$ & 0.000 & $-0.0621 * * *$ & 0.000 & 0.0068 & 0.929 \\
\hline & SIZE & $-0.7552 * * *$ & 0.000 & 0.0399 & 0.276 & -0.7367 & 0.221 \\
\hline & ROE & -0.1137 & 0.187 & $0.2429 * * *$ & 0.002 & $-4.4494 * *$ & 0.033 \\
\hline & NPL & $-0.0049 * * *$ & 0.000 & $0.0024 * * *$ & 0.000 & -0.0014 & 0.486 \\
\hline & Observations & 769 & & 590 & & 169 & \\
\hline & Sargan & 54.6317 & 1.000 & 35.6589 & 1.000 & 7,9445 & 1.000 \\
\hline & $\mathrm{AR}(1)$ & -2.7407 & 0.006 & -2.6646 & 0.008 & -1.8121 & 0.070 \\
\hline & $\mathrm{AR}(2)$ & -0.1060 & 0.916 & 0.7121 & 0.476 & $0.9696 * *$ & 0.332 \\
\hline \multirow[t]{10}{*}{ Model 2} & $\mathrm{BUF}_{\mathrm{i}, \mathrm{t}-1}$ & $0.4728 * * *$ & 0.000 & $0.5699 * * *$ & 0.000 & $0.6573 * * *$ & 0.006 \\
\hline & GDPG & $0.0415 * * *$ & 0.000 & $-0.0506 * * *$ & 0.000 & -0.0056 & 0.947 \\
\hline & SIZE & $-0.7218 * * *$ & 0.000 & 0.0414 & 0.352 & -0.4509 & 0.457 \\
\hline & ROE & $-0.1621 * * *$ & 0.002 & $0.2383 * * *$ & 0.000 & $-4.9023 *$ & 0.081 \\
\hline & NPL & $-0.0052^{* * *}$ & 0.000 & $0.0017 * * *$ & 0.000 & -0.0016 & 0.402 \\
\hline & LOG & $-0.0306 * * *$ & 0.000 & $-0.1476 * * *$ & 0.000 & -0.0043 & 0.383 \\
\hline & Observations & 766 & & 589 & & 167 & \\
\hline & Sargan & 55.2517 & 1.000 & 34.8803 & 1.000 & 7.5534 & 1.000 \\
\hline & $\mathrm{AR}(1)$ & -2.7036 & 0.007 & -2.6901 & 0.007 & -2.2572 & 0.024 \\
\hline & $\mathrm{AR}(2)$ & -0.0346 & 0.972 & 0.8481 & 0.396 & 1.4010 & 0.161 \\
\hline \multirow[t]{11}{*}{ Model 3} & $\mathrm{BUF}_{\mathrm{i}, \mathrm{t}-1}$ & $0.4490 * * *$ & 0.000 & $0.5574 * * *$ & 0.000 & $0.5868 * *$ & 0.012 \\
\hline & GDPG & $0.0216 * * *$ & 0.001 & $-0.0376^{* * *}$ & 0.000 & -0.0202 & 0.837 \\
\hline & SIZE & $-0.8711 * * *$ & 0.000 & 0.0608 & 0.337 & -0.5882 & 0.894 \\
\hline & ROE & $-0.2435 * * *$ & 0.006 & $0.2817 * *$ & 0.030 & -5.0097 & 0.467 \\
\hline & NPL & $-0.0048 * * *$ & 0.000 & $0.0019 * * *$ & 0.000 & 0.0002 & 0.930 \\
\hline & LOG & $-0.0288 * * *$ & 0.000 & $-0.1511 * * *$ & 0.000 & 0.0004 & 0.969 \\
\hline & PROFIT & $0.0113 * * *$ & 0.000 & $0.0027 * * *$ & 0.000 & $0.0358 * *$ & 0.024 \\
\hline & Observations & 766 & & 589 & & 167 & \\
\hline & Sargan & 53.2384 & 1.000 & 31.7826 & 1.000 & 9.8766 & 1.000 \\
\hline & $\mathrm{AR}(1)$ & -2.6607 & 0.008 & -2.6354 & 0.008 & -1.9454 & 0.052 \\
\hline & $\mathrm{AR}(2)$ & -0.3690 & 0.712 & 0.7812 & 0.435 & 1.3439 & 0.179 \\
\hline \multirow[t]{12}{*}{ Model 4} & $\mathrm{BUF}_{\mathrm{i}, \mathrm{t}-1}$ & $0.4491 * * *$ & 0.000 & $0.5599 * * *$ & 0.000 & $0.5328^{*}$ & 0.055 \\
\hline & GDPG & $0.0132 *$ & 0.079 & $-0.0545 * * *$ & 0.000 & -0.1138 & 0.298 \\
\hline & SIZE & $-0.7704 * * *$ & 0.000 & 0.0106 & 0.840 & -5.4438 & 0.261 \\
\hline & ROE & $-0.2465 * * *$ & 0.004 & 0.1720 & 0.113 & -5.9722 & 0.399 \\
\hline & NPL & $-0.0047 * * *$ & 0.000 & $0.0019 * * *$ & 0.000 & -0.0001 & 0.984 \\
\hline & LOG & $-0.0294 * * *$ & 0.000 & $-0.1480 * * *$ & 0.000 & 0.0117 & 0.283 \\
\hline & PROFIT & $0.0110 * * *$ & 0.000 & $0.0022 * * *$ & 0.001 & $0.0414 * *$ & 0.016 \\
\hline & LOTA & $0.0171 * * *$ & 0.000 & $0.0221 * * *$ & 0.000 & -0.0198 & 0.256 \\
\hline & Observations & 766 & & 589 & & 167 & \\
\hline & Sargan & 51.4856 & 1.000 & 31.5448 & 1.000 & 7.9099 & 1.000 \\
\hline & $\mathrm{AR}(1)$ & -2.6565 & 0.008 & -2.6405 & 0.008 & -1.5754 & 0.115 \\
\hline & $\mathrm{AR}(2)$ & -0.3436 & 0.731 & 0.8119 & 0.417 & 1.2249 & 0.221 \\
\hline \multirow[t]{13}{*}{ Model 5} & $\mathrm{BUF}_{\mathrm{i}, \mathrm{t}-1}$ & $0.4488 * * *$ & 0.000 & $0.5599 * * *$ & 0.000 & 0.4522 & 0.254 \\
\hline & GDPG & 0.0048 & 0.571 & $-0.0550 * * *$ & 0.000 & -0.1266 & 0.286 \\
\hline & SIZE & $-0.7772 * * *$ & 0.000 & 0.0239 & 0.666 & -8.1482 & 0.465 \\
\hline & ROE & $-0.1904^{*}$ & 0.077 & 0.1667 & 0.130 & -8.7636 & 0.474 \\
\hline & NPL & $-0.0047 * * *$ & 0.000 & $0.0018 * * *$ & 0.000 & 0.0009 & 0.839 \\
\hline & LOG & $-0.0288 * * *$ & 0.000 & $-0.1488 * * *$ & 0.000 & 0.0186 & 0.500 \\
\hline & PROFIT & $0.0119 * * *$ & 0.000 & $0.0021 * * *$ & 0.002 & 0.0359 & 0.179 \\
\hline & LOTA & $0.0204 * * *$ & 0.000 & $0.0305 * * *$ & 0.000 & -0.0217 & 0.308 \\
\hline & MERGER & $-1.1841 * *$ & 0.037 & 0.1952 & 0.766 & 29.8418 & 0.779 \\
\hline & Observations & 766 & & 589 & & 167 & \\
\hline & Sargan & 50.3880 & 1.000 & 30.9094 & 1.000 & 7.8283 & 1.000 \\
\hline & $\mathrm{AR}(1)$ & -2.6598 & 0.008 & -2.6349 & 0.008 & -0.2520 & 0.801 \\
\hline & $\mathrm{AR}(2)$ & -0.3776 & 0.706 & 0.8169 & 0.414 & 0.5258 & 0.599 \\
\hline
\end{tabular}

Notes: BUF= capital buffer, GDPG $=$ growth of gross domestic product, SIZE $=$ natural logarithm of total assets, ROE $=$ return on equity, $\mathrm{NPL}=$ non-performing loans, $\mathrm{LOG}=$ loan growth, $\mathrm{PROFIT}=$ profit after tax, $\mathrm{LOTA}=$ loans to total assets, $\mathrm{MERGER}=$ merger status of banks. One-step results are presented, whereas the Sargan test refers to two-step estimation results. AR(1) and AR(2) are the tests of first and second order autocorrelation in the residuals. ${ }^{*}, * * * *$ indicate significance at the $0.10,0.05$, and 0.01 levels, respectively. $* * * *$ Banks under the control of Savings Deposit and Insurance Fund. 
We use two-step version of the GMM estimator to obtain the Sargan test statistics (Note 4). All three requirements of the GMM estimation are met in the models structured for the Turkish banking system. Based on the statistics obtained from our analysis, we do not encounter multicollinearity between the explanatory variables. In the main model, for commercial banks, we find a positive significant relation (p-value: 0.000 ) between capital buffer and GDPG. An increase of $1 \%$ in the GDPG is associated with an increase of $0.03 \%$ in the capital buffer. The positive 0.50 coefficient of the lagged dependent variable indicates that this cyclical impact increases after one year. The positive relation between capital buffer and GDPG turns out to countercyclical when we exclude the SDIF banks. This result suggests that this group of banks tend to cover the risks in downturns with higher capital reserves.

In literature we find Ayuso et al. (2004), Lindquist (2004), Stolz and Wedow $(2005,2011)$ and partially Jokipii and Milne (2008) report a negative relation between bank capital buffers and cycle variables for Spanish, Norwegian, German and European banks, respectively. Bikker and Metzemakers (2007) also discuss a negative relation between capital buffers and cycle in their cross-country analysis for 29 OECD countries. Our findings for commercial banks excluding the SDIF banks are in line with the literature. On the other hand, findings for commercial banks including the SDIF banks are not consistent with the literature indicating that commercial banks most probably use capital buffers to offset the negative effects of procyclical requirements. Turning to the bank-specific variables of commercial banks, we find a negative significant relation (p-value: 0.000 ) between capital buffer and SIZE suggesting that the larger the bank the lower its capital ratio. This finding leads us to economies of scale, diversification effects and advantages in terms of accessing to capital, which is consistent with the findings of Alfon and Argimon (2005), Fonseca and Gonzales (2010), Lindquist (2004) and Stolz and Wedow $(2005,2011)$. When we exclude the SDIF banks, the relation becomes insignificant.

The relation between the second bank-specific variable ROE and capital buffer is insignificant for commercial banks. Excluding the SDIF banks, the relation turns out to be significantly positive (p-value: 0.002) suggesting that information asymmetries may lead to an increase in retained earnings that cause to an increase in capital ratio as also reported by Berger (1995), Nier and Baumann (2006) and Flannery and Rangan (2008). The relation of capital buffer and NPL is found significantly negative (p-value: 0.000 ), indicating that the higher the banks risk preferences, the lower the capital buffers they hold. This result is consistent with the literature. When we exclude the SDIF banks, the relation becomes significantly positive (p-value: 0.000 ) which is in line with the study of Jokipii and Milne (2008).

For the consistency of GMM estimation, Sargan statistics is used. In the main model, the result is fully satisfactory in favor of the validity of the instruments. There is a significant negative first-order autocorrelation in the residuals, AR(1) statistics, as expected and no second-order serial correlation in the first-difference correlations, AR(2) statistics. The results are still fully satisfactory for the commercial banks and commercial banks excluding the SDIF banks. Table 1 presents further estimation results for the four models derived from the main model. In the first step, LOG is added to the main model as an explanatory variable and a significantly negative relation is found out between capital buffer and LOG (p-value: 0.000) for the commercial banks. This finding suggests that an unexpected increase in loan demand may lead to a decrease in the capital buffer. On the other hand, an increase in loans may lead to an increase in capital requirements. When, adjusting capital is costly, it may reduce capital buffers, as well. The relation is still significantly negative (p-value: 0.000 ) when we exclude the SDIF banks.

As a second step, we extend the model by adding PROFIT to the main model as an explanatory variable. The relation between capital buffer and PROFIT is significantly positive (p-value: 0.000 ) for commercial banks indicating that retained earnings are used to increase the capital buffer. The result is still significantly positive (p-value: 0.000 ) when we exclude the SDIF banks. As a third step, we extend the main model by adding LOTA as an explanatory variable. The relation between capital buffer and LOTA is significantly positive (p-value: 0.000 ) suggesting that banks prefer holding higher capital buffer towards a riskier profile. The relation remains significantly positive (p-value: 0.000 ) when we exclude the SDIF banks.

Our last extension to the main model as an explanatory variable is MERGER. This variable shows a significant negative sign (p-value: 0.037) implying that MERGER has an adverse effect on capital buffer. This finding could address a capital-consuming merger or a merger between a well-capitalized bank and a weak one for rescuing the second. The relation is insignificant when we exclude the SDIF banks. GMM Sargan test results, $A R(1)$ and $A R(2)$ statistics are satisfactory for the main model and its extensions derived for commercial banks and commercial banks excluding the SDIF banks. 
We structured an additional model by including output gap (OUTGAP) and SDIF to provide further evidence on the capital buffer procyclicality and to examine the effects of the SDIF banks in detail. We replaced the GDPG in the main model with OUTGAP as a new measure of business cycle in order to capture the possibility of non-constant potential output growth. We applied the Hodrick-Prescott filter-the mathematical tool to separate the cyclical component of the time series from raw data- to the real GDP series in order to investigate the OUTGAP. We analyze the results with the model stated in Equation (2).

$$
\boldsymbol{B} \boldsymbol{U} \boldsymbol{F}_{i t}=\alpha_{0} B U F_{i, t-1}+\alpha_{1} S_{I Z E_{i t}}+\alpha_{2} R_{\text {OE }}+\alpha_{3 t} N P L_{i t}+\alpha_{4} \text { OUTGAP }_{i t}+n_{i}+\varepsilon_{i t}
$$

We analyze the effects of the presence of the SDIF banks with the model stated in Equation (3).

$$
\boldsymbol{B} \boldsymbol{U} \boldsymbol{F}_{i t}=\alpha_{0} B U F_{i, t-1}+\alpha_{1} G D P G_{i t}+\alpha_{2} S I Z E_{i t}+\alpha_{3} R O E_{i t}+\alpha_{4} N P L_{i t}++\alpha_{5} S D I F_{i t}+\alpha_{6} M E R G E R_{i t}+n_{i}+\varepsilon_{i t}
$$

Our findings are listed in Table 2.

\begin{tabular}{|c|c|c|c|c|c|c|c|}
\hline & & \multicolumn{2}{|c|}{ Commercial banks } & \multicolumn{2}{|c|}{ Commercial banks excluding SDIF banks } & \multicolumn{2}{|c|}{ Development and investment banks } \\
\hline & & Coef. & P-value & Coef. & P-value & Coef. & P-value \\
\hline \multirow[t]{9}{*}{ Model 1.A } & $\mathrm{BUF}_{\mathrm{i},-1}$ & $0,4884 * * *$ & 0,000 & $0.5807 * * *$ & 0.000 & $0,6482 * * *$ & 0,000 \\
\hline & SIZE & $-0,7562 * * *$ & 0,000 & 0.0411 & 0.509 & $-0,7478$ & 0,152 \\
\hline & ROE & $-0,1513^{* *}$ & 0,019 & $0.1744 * *$ & 0.029 & $-6,8480 * * *$ & 0,007 \\
\hline & NPL & $-0,0049 * * *$ & 0,000 & $0.0021 * * *$ & 0.000 & $-0,0010$ & 0,660 \\
\hline & OUTGAP & $0,0391 * * *$ & 0,000 & $-0.1435^{* * *}$ & 0.000 & $-0,1813$ & 0,127 \\
\hline & Observations & 769 & & 590 & & 169 & \\
\hline & Sargan & 56,0500 & 1,000 & 36.9003 & 1.000 & 8,5960 & 1,000 \\
\hline & $\mathrm{AR}(1)$ & $-2,7321$ & 0,006 & -2.6688 & 0.007 & $-2,3195$ & 0,020 \\
\hline & $\mathrm{AR}(2)$ & $-0,1133$ & 0,909 & 0.7132 & 0.476 & 1,0019 & 0,316 \\
\hline \multirow[t]{11}{*}{ Model 1.B } & $\mathrm{BUF}_{\mathrm{i}, \mathrm{t}-1}$ & $0,5264 * * *$ & 0,000 & $0.5801 * * *$ & 0.000 & $0,5474 *$ & 0,062 \\
\hline & GDPG & $0,0303 * * *$ & 0,000 & $-0.0599 * * *$ & 0.000 & 0,0046 & 0,961 \\
\hline & SIZE & $-0,0929 * *$ & 0,047 & -0.0568 & 0.193 & $-0,7080$ & 0,551 \\
\hline & ROE & $-0,1351$ & 0,297 & $0.2355^{* * *}$ & 0.001 & $-4,5237 * *$ & 0,032 \\
\hline & NPL & $-0,0042 * * *$ & 0,000 & $0.0025^{* * *}$ & 0.000 & $-0,0014$ & 0,510 \\
\hline & SDIF & $-1,8708 * * *$ & 0,000 & N.A & N.A & N.A. & N.A. \\
\hline & MERGER & 0,5049 & 0,152 & 0.1572 & 0.629 & $-0,7200$ & 0,986 \\
\hline & Observations & 769 & & 590 & & 169 & \\
\hline & Sargan & 55,54 & 1,000 & 32.8467 & 1.000 & 7,9485 & 1,000 \\
\hline & $\mathrm{AR}(1)$ & $-2,7808$ & 0,005 & -2.6472 & 0.008 & $-1,9581$ & 0,050 \\
\hline & $\mathrm{AR}(2)$ & $-0,1467$ & 0,883 & 0.7237 & 0.469 & 1,0792 & 0,281 \\
\hline
\end{tabular}

Table 2. Additional GMM estimation results

Notes: $\mathrm{BUF}=$ capital buffer, $\mathrm{SIZE}=$ natural logarithm of total assets, $\mathrm{ROE}=$ return on equity, $\mathrm{NPL}=$ non-performing loans, $\mathrm{OUTGAP}=$ output gap, GDPG= growth of gross domestic product, $\mathrm{SDIF}=$ banks under the control of Savings Deposit and Insurance Fund, MERGER= merger status of banks, N.A.=Not Available. One- step results are presented, whereas the Sargan test refers to two-step estimation results. AR(1) and $\mathrm{AR}(2)$ are the tests of first and second order autocorrelation in the residuals. *,**,*** indicate significance at the $0.10,0.05$, and 0.01 levels, respectively.

In Model 1.A, the result for commercial banks indicates that the procyclicality remains when we replace the variables GDPG and OUTGAP. The relation between the capital buffer and OUTGAP variable is significantly (p-value: 0.000 ) positive suggesting that the commercial banks in Turkey tend to undertake extra risks of the business cycle downswings with less capital. When we exclude the SDIF banks, the relation of capital buffer and OUTGAP represents a countercyclical behavior in parallel to the findings of the main model.

In Model 1.B, we include the SDIF banks as a dummy variable and find a significantly negative (p-value: 0.000) relation. Result points out a countercyclical behavior of the SDIF banks suggesting that the existence of these group of banks are capital buffer eroding as witnessed in years 1999 and 2000.

GMM Sargan test results, AR(1) and AR(2) statistics are successful both for Equation (2) and Equation (3) with their significantly expected signs. Results point out that no model misspecifications exist.

\section{Discussion and Further Research Ideas}

The increasing frequency of global financial crises makes it clear that there is no safe haven in the world of intra and interdependent economies due to globalization and increasing market integration. In this new global 
environment, developed economies are much more sensitive to global financial crises compared to emerging markets. In this respect, Turkey appears to have a better-positioned banking system among the emerging markets due to the improvements in her financial system after the drastic banking and liquidity crisis in 2000 and 2001. Turkish banking sector has learned a lot and developed substantial amount of precautionary and structural measures, especially on the capital buffering approach by the ongoing crises in the last two decades. This approach seems to be working properly for the Turkish banks, which proved themselves in the latest global financial crisis. Inverse funding and profitability in the banking system even under a global financial crisis environment could be evaluated as yields of this evolving financial system. The risk management system of the Turkish banking sector can be summarized by effective public supervision, risk avoiding attitude and capital buffering approach. In this study, we focus on exploring the determinants of capital buffers in the Turkish banks, through the estimation of a dynamic panel data model. We have gathered the data from Banks Association of Turkey for 938 observations of 87 banks for a period from 1988 to 2009 .

We build our model by using two-step version of GMM methodology for the commercial banks, commercial banks excluding the SDIF banks and development and investment banks. Because the development and investment banks have their own business dynamics and specialization, we opt to focus on the commercial banks and commercial banks excluding the high risky banks that are transferred to the control of the SDIF due to their drastic financial and governance problems especially after the 2001 financial crisis.

Our findings provide sufficient evidence about a procyclical relation between the capital requirements and business cycles for the Turkish commercial banks and a countercyclical relation for the commercial banks excluding the SDIF banks. Although recent research results on cyclicality in literature are mixed, an overwhelming majority of results refer in favor of a countercyclical relation. Considering the recent countercyclical proposal under BASEL III, our results for commercial banks excluding the problematic banks could be evaluated as in line with the expected future results. According to the results of the main model the relation between capital buffer and size is significantly negative and in line with the related literature for commercial banks. This result not only supports the fact that the larger banks have lower capital ratios but also reveals economies of scale, diversification effects and advantages in terms of access to capital. Capital buffer and ROE relation is found significantly positive for the commercial banks excluding the SDIF banks, suggesting that information asymmetries could lead to an increase in retained earnings, which could cause an increase in capital ratios. Capital buffer and NPL relation is significantly negative for commercial banks, leading us to conclude that the higher the risk preference of banks the lower the capital buffers they hold. This finding is also in line with the literature. This relation turns significantly positive when we exclude the SDIF banks. The relation of capital buffer and LOG is significantly negative for both the commercial banks and commercial banks excluding the SDIF banks, revealing that an unexpected increase in loan demand may lead to a decrease in the capital buffer. Besides, an increase in loans may lead to an increase in capital requirements. When adjusting capital is costly, it may reduce capital buffers as well. The relation between capital buffer and PROFIT is significantly positive for the commercial banks and commercial banks excluding the SDIF banks, indicating that retained earnings used to increase the capital buffer. The relation between capital buffer and LOTA is significantly positive for the commercial banks and commercial banks excluding the SDIF banks. This finding stresses that banks choose to hold higher capital buffers for the higher risk levels, which is in parallel with the previous findings in literature. MERGER has an adverse effect on capital buffer in commercial banks. This finding addresses a capital-consuming merger or a merger between a well- capitalized bank and a weak one for rescuing the second.

As a different measure of economic activity, we establish an additional model to provide further evidence on the capital buffer procyclicality and to examine the effects of the banks under the control of the SDIF in detail. We replace the GDPG by OUTGAP by using Hodrick Prescott filter. This replacement does not change the results of the main model established for commercial banks and commercial banks excluding the problematic banks. Moreover, in the second additional model, we include the SDIF banks as a dummy variable and results for commercial banks point out a countercyclical behavior of the SDIF banks suggesting that these problematic banks are capital buffer eroding as witnessed in years 1999 and 2000.

Overall, this study intends to shed some light on the determinants of capital buffer and the cyclicality relation of the Turkish banking system. Our findings provide sufficient evidence about a procyclical relation between the capital requirements and business cycles for the Turkish commercial banks and a countercyclical relation for the commercial banks excluding the SDIF banks. Eliminating the problematic SDIF banks, our findings lead us to conclude that Turkish commercial banks employ the capital buffering approach proposed under BASEL III as an effective risk management tool besides the other vehicles. The empirical results points out that capital buffer is 
affected mainly by non-performing loans (NPL), loan growth (LOG), profit after tax (PROFIT) and loans to total assets (LOTA). Considering the commercial banks excluding SDIF banks, capital buffer and NPL relation is significantly positive showing that these banks adopt conservative position against risks. LOG and capital buffer relation is significantly negative revealing that an unexpected increase in loan demand may lead to a decrease in the capital buffer. The relation between capital buffer and PROFIT is significantly positive indicating that retained earnings used to increase the capital buffer. Finally, relation between capital buffer and LOTA is significantly positive stressing that banks choose to hold higher capital buffers for the higher risk levels. Structuring the models by covering different variables and applying different methodologies and/or including banking sectors of emerging countries could be the subject for future studies.

\section{References}

Alfon, I., Argimón, I., \& Bascuñana-Ambrós, P. (2005). How individual capital requirements affect capital ratios in UK banks and building societies. Banco de España Working Papers No. 515.

Arellano, M., \& Bond, S. (1991). Some tests of specification for panel data: Monte Carlo evidence and an application to employment equations. The Review of Economic Studies, 58, 277-297. http://dx.doi.org/10.2307/2297968

Atici, G., \& Gursoy, G. (2011). Financial crises and capital buffer: Evidence from the Turkish banking sector. Banks and Bank Systems International Research Journal, 6, 72-86.

Ayuso, J., Perez, D., \& Saurina, J. (2004). Are capital buffers pro-cyclical? Evidence from Spanish panel data. Journal of Financial Intermediation, 1, 249-264. http://dx.doi.org/10.1016/S1042-9573(03)00044-5

Bank for International Settlements. (2004). International convergence of capital measurement and capital standards. Basel.

Banking Regulation and Supervision Agency. (2012). An outlook to the Turkish banking system. Report No. 2012/2. Ankara: Author.

Berger, A. N. (1995). The relationship between capital and earnings in banking. Journal of Money, Credit and Banking, 27, 432-456. http://dx.doi.org/10.2307/2077877

Bikker, J. A., \& Metzemakers, P. A. J. (2007). Is bank capital procyclical? A cross-country analysis. Kredit und Kapital, 40, 225-264.

Boucinha, M. (2008). The determinants of Portuguese banks' capital buffers. Banco de Portugal Working papers No.1.

Caporale, G. M., Raul, T. C., Sova, R. A., \& Sova, A. D. (2009). Financial development and economic growth: Evidence from ten new EU members. German Institute for Economic Research Discussion Paper No. 940.

Danielsson, J., Embrechts, P., Goodhart, C., Keating, C., Muennich, F., Renault, O., \& Shin, H. S. (2001). An academic response to Basel II (No. 130). London School of Economics, Financial Markets Group Special Paper Series.

Eichberger, J., \& Summer, M. (2005). Bank capital, liquidity and systemic risk. Journal of the European Economic Association, 3, 547-555.

Estrella, A. (2004). The cyclical behavior of optimal bank capital. Journal of Banking and Finance, 28, 1469-1498. http://dx.doi.org/10.1016/S0378-4266(03)00130-4

Flannery, M. J., \& Rangan, K. P. (2008). What caused the bank capital build-up of the 1990s? Review of Finance, 12, 391-429. http://dx.doi.org/10.1093/rof/rfm007

Fonseca, A. R., \& González, F. (2010). How bank capital buffers vary across countries: The influence of cost of deposits, market power and bank regulation. Journal of Banking and Finance, 34, 892-902. http://dx.doi.org/10.1016/j.jbankfin.2009.09.020

Goddard, J., Molyneux, P., \& Wilson, J. O. S. (2004). The profitability of European banks: A cross-sectional and dynamic panel analysis. The Manchester School, 72, 363-381. http://dx.doi.org/10.1111/j.1467-9957.2004.00397.x

Heuvel, S. J. (2008). The welfare cost of bank capital requirements. Journal of Monetary Economics, 55, 298-320. http://dx.doi.org/10.1016/j.jmoneco.2007.12.001

Jackson, P. (1999). Capital requirements and bank behavior: The impact of the Basel accord. Basel Committee on Banking Supervision Working Papers No. 1. 
Jokipii, T., \& Milne, A. (2008). The cyclical behavior of European bank capital buffers. Journal of Banking and Finance, 32, 1440-1451. http://dx.doi.org/10.1016/j.jbankfin.2007.12.001

Kleff, V., \& Weber, M. (2003). How do banks determine capital? Empirical evidence for Germany. Centre for European Economic Research Discussion Paper No. 03-66.

Lindquist, K. G. (2003). Banks' buffer capital: How important is risk? Norges Bank Working Papers No. 11.

Lindquist, K. G. (2004). Banks' buffer capital: How important is risk? Journal of International Money and Finance, 23, 493-513. http://dx.doi.org/10.1016/j.jimonfin.2004.01.006

Marcus, A. J. (1984). Deregulation and bank financial policy. Journal of Banking and Finance, 8, 557-565. http://dx.doi.org/10.1016/S0378-4266(84)80046-1

Milne, A. (2004). The inventory perspective on bank capital. Cass Business School Research Paper No. 576062.

Milne, A., \& Whalley, A. E. (2001). Bank capital regulation and incentives for risk taking. Cass Business School Research Paper.

Modigliani, F., \& Miller, M. H. (1958). The cost of capital, corporation finance and the theory of investment. The American Economic Review, 48, 261-297.

Nier, E., \& Baumann, U. (2006). Market discipline, disclosure and moral hazard in banking. Journal of Financial Intermediation, 15, 332-361. http://dx.doi.org/10.1016/j.jfi.2006.03.001

Pederzoli, C., \& Torricelli, C. (2005). Capital requirements and business cycle regimes: Forward-looking modeling of default probabilities. Journal of Banking and Finance, 29, 3121-3140. http://dx.doi.org/10.1016/j.jbankfin.2005.01.004

Peura, S., \& Jokivuolle, E. (2004). Simulation based stress tests of banks' regulatory capital adequacy. Journal of Banking and Finance, 28, 1801-1824. http://dx.doi.org/10.1016/j.jbankfin.2003.05.005

Stolz, S. M. (2007). Bank capital and risk-taking: The impact of capital regulation, charter value and the business cycle. Germany: Springer.

Stolz, S., \& Wedow, M. (2005). Banks' regulatory capital buffer and the business cycle: Evidence for German savings and cooperative banks. Deutsche Bundesbank Banking and Financial Studies Discussion Paper No. $07 / 2005$.

Stolz, S., \& Wedow, M. (2011). Banks' regulatory capital buffer and the business cycle: Evidence for Germany. Journal of Financial Stability, 7, 98-110. http://dx.doi.org/10.1016/j.jfs.2009.09.001

\section{Notes}

Note 1. Furfine (2000) -U.S. banks, Rime (2001) - Swiss banks, Kleff and Weber (2003) - German banks, Ayuso et al. (2004) - Spanish banks, Lindquist (2004) - Norwegian banks, Stolz and Wedow (2005, 2011) -German banks, Boucinha and Ribeiro (2007) Portuguese banks and Tabak et al. (2011) Brazilian Banks.

Note 2. Target ratio is set according to the Banking Regulation and Supervision Agency (BRSA) Board Decision No: 2026, dated November 16, 2006.

Note 3. The Arellano-Bond (1991) estimator is a GMM estimator for linear dynamic panel-data models that uses lagged levels of the endogenous variables as well as first differences of the exogenous variables as instruments. It removes the panel-specific heterogeneity by first-differencing the regression equation.

Note 4. For more details, see Arellano and Bond (1991).

\section{Appendix A. Distribution of Turkish Banks}

\begin{tabular}{ll}
\hline Type of Banks & Number of Banks \\
\hline Development and Investment Banks & 18 \\
Commercial Banks & 69 \\
SDIF* Banks (in commercial banks) & 20 \\
Banking Sector (All banks) & 87 \\
\hline
\end{tabular}

Note: *Banks under the control of the Savings Deposit and Insurance Fund. 


\section{Appendix B. Descriptive Statistics}

\begin{tabular}{lllll}
\hline Commercial Banks (1988-2009) & Mean & Std. Dev. & Minimum & Maximum \\
\hline Variable & 6.17 & 21.03 & -308.90 & 92.20 \\
\hline BUF & 3.77 & 4.90 & -6.09 & 9.37 \\
GDPG & 18.03 & 3.61 & 8.62 & 25.55 \\
SIZE & 0.33 & 1.27 & -25.11 & 13.30 \\
ROE & 32.99 & 295.86 & 0.00 & 7554.58 \\
NPL & 6.06 & 116.99 & -0.99 & 3463 \\
LOG & 60.49 & 381.73 & -5264.86 & 3150.96 \\
PROFIT & 35.80 & 30.51 & 0.00 & 509.08 \\
LOTA & Mean & Std. Dev. & & Maximum \\
\hline Commercial Banks excluding SDIF* banks $(\mathbf{1 9 8 8 - 2 0 0 9 )}$ & 12.79 & -33.40 & 76.90 \\
Variable & 8.41 & 4.90 & -6.09 & 9.37 \\
\hline BUF & 3.77 & 3.75 & 9.73 & 25.55 \\
GDPG & 18.32 & 1.31 & -25.11 & 6.83 \\
SIZE & 0.31 & 145.11 & 0.00 & 3759.06 \\
ROE & 13.67 & 128.43 & -0.99 & 3463 \\
NPL & 3.97 & -1543.01 & 3150.96 \\
LOG & 93.70 & 0.00 & 75.12 \\
PROFIT & 33.92 & 17.53 & & Minimum \\
LOTA &
\end{tabular}

Notes: $\mathrm{BUF}=$ capital buffer, $\mathrm{GDPG}=$ growth of gross domestic product, $\mathrm{SIZE}=$ natural logarithm of total assets, $\mathrm{ROE}=$ return on equity, $\mathrm{NPL}=$ non-performing loans, $\mathrm{LOG}=$ loan growth, PROFIT $=$ profit after tax and LOTA=loans to total assets. * Banks under the control of Savings Deposit and Insurance Fund.

\section{Appendix C. The Correlation Matrix of the Variables}

\begin{tabular}{|c|c|c|c|c|c|c|c|c|}
\hline \multicolumn{9}{|c|}{ Commercial Banks } \\
\hline & Buffer & $G D P G$ & $L O G$ & $R O E$ & $N P L$ & $L O G$ & PROFIT & LOTA \\
\hline BUF & 1.0000 & & & & & & & \\
\hline GDPG & 0.0168 & 1.0000 & & & & & & \\
\hline LOG & -0.1453 & -0.0681 & 1.0000 & & & & & \\
\hline ROE & -0.0708 & 0.0888 & -0.0713 & 1.0000 & & & & \\
\hline NPL & -0.1734 & 0.0191 & 0.0241 & 0.0184 & 1.0000 & & & \\
\hline LOG & 0.0218 & 0.0375 & -0.0318 & 0.0018 & -0.0100 & 1.0000 & & \\
\hline PROFIT & 0.1476 & 0.0162 & 0.3201 & -0.0195 & -0.0554 & -0.0106 & 1.0000 & \\
\hline LOTA & -0.0487 & 0.0504 & -0.0348 & -0.0233 & -0.1009 & -0.0297 & 0.0436 & 1.0000 \\
\hline \multicolumn{9}{|c|}{ Commercial Banks excluding SDIF* Banks } \\
\hline & Buffer & $G D P G$ & $L O G$ & $R O E$ & $N P L$ & $L O G$ & PROFIT & LOTA \\
\hline BUF & 1.0000 & & & & & & & \\
\hline GDPG & -0.0199 & 1.0000 & & & & & & \\
\hline LOG & -0.2717 & -0.0636 & 1.0000 & & & & & \\
\hline ROE & 0.0179 & 0.1008 & -0.0864 & 1.0000 & & & & \\
\hline NPL & 0.1900 & 0.0242 & -0.0111 & -0.0429 & 1.0000 & & & \\
\hline LOG & 0.0381 & 0.0353 & -0.0317 & 0.0037 & -0.0213 & 1.0000 & & \\
\hline PROFIT & -0.0520 & -0.0259 & 0.4193 & 0.0335 & -0.0263 & -0.0387 & 1.0000 & \\
\hline LOTA & -0.2500 & 0.0787 & 0.1252 & 0.0272 & -0.1124 & -0.0491 & 0.1153 & 1.0000 \\
\hline
\end{tabular}

Notes: $\mathrm{BUF}=$ capital buffer, $\mathrm{GDPG}=$ growth of gross domestic product, $\mathrm{SIZE}=$ natural logarithm of total assets, $\mathrm{ROE}=$ return on equity, $\mathrm{NPL}=$ non-performing loans, $\mathrm{LOG}=$ loan growth, $\mathrm{PROFIT}=$ profit after tax and LOTA= loans to total assets. *Banks under the control of Savings Deposit and Insurance Fund.

\section{Appendix D. Capital Requirements for the Turkish Banks}

\begin{tabular}{lll}
\hline Minimum Required Ratio & Year of the Implementation & Target Ratio \\
\hline $5 \%$ & 1989 & - \\
$6 \%$ & 1990 & - \\
$7 \%$ & 1991 & - \\
$8 \%$ & 1992 to 2009 & $12 \% *$ \\
\hline
\end{tabular}

Source: Banking Regulation and Supervision Agency

Notes: *Target ratio is declared by Banking Regulation and Supervision Agency Board Decision No: 2026 dated November 16, 2006. 